\title{
PENGOLAHAN LIMBAH KOTORAN SAPI MENJADI ENERGI GAS NON FOSIL DAN PUPUK ORGANIK DI DESA BATU KUTA LOMBOK BARAT
}

\author{
Abyadul Fitriyah"), Ria Harmayani1"), Aisah Jamili1), Yuni Mariani'1), Ni Made Andry Kartika1), \\ Isyaturriyadhah')
}

1Universitas Nahdlatul Wathan Mataram, JI. Kaktus 1-3 Kota Mataram 83125 NTB

${ }^{2}$ Universitas Muara Bungo Jambi, Jambi Jl. Pendidikan, Sungai Binjai, Kec. Batin III, Kab. Bungo, Jambi 37211 Jambi

\author{
Corresponding author : Abyadul Fitriyah \\ E-mail : abyadulfitriyah@gmail.com
}

Diterima 29 Juli 2021, Direvisi 06 Agustus 2021, Disetujui 06 Agustus 2021

\begin{abstract}
ABSTRAK
Kegiatan pengabdian masyarakat (PPM) ini bertujuan pemberdayaan masyarakat pada Kelompok Tani Ternak (KTT) di desa Batu Kuta Lombok Barat dalam memanfaatkan limbah kotoran sapi yang melimpah untuk membuat instalasi energi gas non fosil, dan pembuatan pupuk kompos. Metode yang diterapkan oleh Tim PPM meliputi, sosialisasi/penyuluhan dan pelatihan/workshop pembuatan pupuk kompos dan pembuatan instalasi energi gas non fosil (biogas) yang diikuti dengan pelatihan pengoperasian dan perawatannya serta pemasaran produk. Hasil kegiatan menunjukkan bahwa program PPM berlangsung dengan baik dan lancar. Program ini mampu memberi motivasi kepada petani peternak KTT Wirasinge di desa Batu Kuta Lombok Barat dalam memanfaatkan limbah kotoran ternak menjadi bahan bakar biogas dan pupuk kompas yang secara tidak langsung akan meningkatkan pendapatan dan kesejahteraan masyarakat. Kendala-kendala yang muncul pada tahap pelaksanaan kegiatan PPM dapat diatasi dengan metode monitoring, evaluasi dan pendampingan. Penerapan teknologi yang dilaksanakan di Desa Batu Kuta telah menghasilkan biogas sebagai sumber energi alternatif bagi peternak. Saran yang dapat diajukan dari hasil kegiatan PPM ini bagi masyarakat desa Batu Kuta, diharapkan untuk tetap melanjutkan program ini dan perlunya pendampingan dalam pengelolaan keuangan. Bagi pemerintah daerah diharapkan dapat mensosialisasikan program ini untuk diterapkan pada masyarakat di daerah atau desa lain dengan kondisi pertanian dan peternakan yang memadai. Bagi pemerintah pusat hendaknya selalu meluncurkan program sejenis untuk terus dapat dilaksanakan dan dikembangkan dalam rangka membantu masyarakat di pedesaan yang terdampak langsung dari efek pandemik dan merasakan terpuruknya keadaan ekonomi.
\end{abstract}

Kata kunci: limbah kotoran sapi; gas non fosil; pupuk organic

\begin{abstract}
The Community Service Program (PPM) is aimed for community development of ranchers group at Batu Kuta West Lombok, to use the abundant cow manure in making non-fossil fuel installation as well as compost fertilizer. The PPM Team employed socialization and workshop in making non-fossil fuel installation (biogas) and compost fertilizer, followed by workshops in operating, maintenance, and product marketing. The results revealed the PPM Team program was executed accordingly, providing motivations to Wirasinge's ranchers Group at Batu Kuta by turning cow manure into non-fossil fuel biogas and compost fertilizer which indirectly improved the people's income and prosperity. Meanwhile, the Problems encountered were solved using monitoring, evaluation, and accompaniment. Further, the technology implementation outcome is the biogas, which becomes the ranchers's alternative energy source. It is suggested by the PPM team for the Wirasinge ranchers Group or people at Batu Kuta to continue with the program and initiate accompaniment in financial management, while the local government is expected to socialize the program in other villages with adequate cattle conditions. The central government is also expected to initiate and develop similar programs often, to help the villagers' from the pandemic effect and worsened economical conditions.
\end{abstract}

Keywords: cow manure; non-fossil fuel; organik fertilizer

\section{PENDAHULUAN}

Masyarakat pedesaan di wilayah terpencil yang terdampak langsung dari efek pandemik ini merasakan terpuruknya keadaan ekonomi. Bahkan untuk memenuhi kebutuhan sehari-hari pun terasa sangat berat, mulai dari mendapatkan bahan makanan pokok sampai memperoleh bahan bakar untuk mengolah 
bahan makanan tersebut. Disamping itu beberapa kebutuhan pokok sudah meningkat harganya, tak terkecuali bahan bakar seperti gas, bensin, dan minyak tanah yang mulai langka, sehingga beberapa masyarakat pedesaan Kembali menggunakan kayu bakar untuk mengolah bahan makanan.

Desa Batu Kuta Kecamatan Narmada Kabupaten Lombok Barat memiliki potensi cukup besar dibidang peternakan, pertanian, perikanan dan aneka usaha yang lain. Potensi peternakan sapi cukup besar dimiliki masyarakat Desa Batu Kuta. Dengan jumlah peternak sapi dan kambing 75 orang dan jumlah sapi mencapai 339 ekor (Statistik, 2020). Adapun permasalahan yang dihadapi antara lain, sampai saat ini kotoran sapi hanya ditumpuk dan dibiarkan begitu saja di pinggir kandang, belum dimanfaatkan untuk menghasilkan produk yang lebih bermanfaat, misalnya, instalasi energi gas non fosil, pupuk kompos yang bernilai ekonomi tinggi dan lainnya (Wikipedia, 2020).

Kotoran sapi yang umumnya dimanfaatkan sebagai pupuk kandang, dapat juga diolah menjadi produk energi gas non fosil atau energi terbarukan berupa biogas, sehingga menghasilkan energi bagi kebutuhan rumah tangga. Biogas adalah salah satu energi non fosil yang dapat dikembangkan dengan memberikan cukup bahan baku dan re-newable berupa kotoran sapi (CARE, 2009). Dengan demikian masalah kebutuhan energi dapat diatasi dengan menggunakan sumber energi terbarukan yang relative mudah didapat, biaya operasional yang rendah, tidak mengakibatkan masalah limbah, karena limbah dari teknologi biogas ini berupa pupuk organik (pupuk kompos) yang memiliki nilai jual sebagai pengganti pupuk non-organik.

Pengolahan limbah biogas atau kotoran sapi menjadi pupuk kompos merupakan usaha yang dapat dikerjakan secara sampingan. Walaupun hanya sebagai usaha sampingan kotoran sapi ini memiliki prospek yang sangat bagus, karena pupuk dari kotoran sapi mempunyai nilai jual dan ekonomi yang cukup tinggi. Saat ini kotoran sapi hanya ditumpuk dan dibiarkan begitu saja di pinggir kandang. Kalaupun toh ada upaya mencoba untuk pembuatan pupuk kompos dari kotoran sapi hanya terbatas coba-coba, dan belum memberikan nilai ekonomis bagi masyarakat. Pengolahan kotoran sapi menjadi pupuk kompos belum atau tidak dilakukan dengan memanfaatkan teknologi secara profesional.

Berdasarkan uraian tersebut, Tim Pengabdian Pada Masyarakat (PPM) Universitas Nahdlatul Wathan Mataram (UNW Mataram) mengadakan Kegiatan PPM dengan tujuan membantu mengatasi beberapa permasalahan yang ada di desa Batu Kuta Lombok Barat sebagai mitra Tim PPM UNW Mataram. Solusi yang diterapkan untuk mengatasi masalah tersebut yaitu melalui kegiatan Pemberdayaan masyarakat dengan memanfaatkan limbah kotoran sapi menjadi energi gas non fosil, dan pupuk kompos.

Dengan adanya kegiatan pemberdayaan ini, diharapkan dapat membantu masyarakat desa Batu Kuta dalam meningkatkan pendapatan dan kesejahteraannya.

\section{METODE}

Pelatihan atau workshop tentang "Pengolahan Limbah Kotoran Sapi menjadi Energi Gas Non Fosil dan Pupuk Organik" dilaksanakan pada tanggal 23 Maret 2021, dihadiri oleh 40 orang petani peternak dari Kelompok Tani Ternak (KTT) Wiresange, desa Batu Kuta, Kecamatan Narmada, Kabupaten Lombok Barat.

Adapun kegiatan utama yang telah dilaksanakan dalam kegiatan pemberdayaan masyarakat di desa Batu Kuta Lombok Barat, meliputi beberapa kegiatan yaitu;

1. Pelatihan/workshop cara pemanfaatan kotoran sapi menjadi energi gas non fosil

2. Perancangan sistem instalasi energi gas non fosil sesuai dengan lokasi

3. Pembuatan sistem instalasi energi gas non fosil dan distribusi dilokasi rumah tangga terdekat

4. Pelatihan/workshop tentang pembuatan kompos dari kotoran sapi.

5. Pembuatan pupuk kompos dari kotoran sapi yang dilanjutkan dengan proses pengemasan dan pemasaran produk pupuk kompos

6. Monitoring dan evaluasi serta pendampingan

Instalasi biogas terdiri dari bangunan utama yaitu digester yang berfungsi untuk menampung gas metan hasil fermentasi bahanbahan organik oleh bakteri. Digester sebaiknya disesuaikan dengan kondisi disetiap rumah. Adapun bahan yang diperlukan untuk membuat digester yaitu pasir, semen, batu kali, batu koral, bata merah, besi konstruksi, cat dan pipa PVC. Jenis digester yang digunakan pada kegiatan ini adalah model continuous feeding dimana pengisian bahan organiknya dilakukan secara continue setiap hari.

\section{Tahapan Pembuatan Biogas Kotoran Sapi}

Setelah peralatan digester selesai dipasang, maka dilanjutkan dengan tahap pembuatan biogas dari kotoran sapi dengan cara sebagai berikut : 
1. Kotoran sapi dicampur dengan air hingga terbentuk lumpur dengan perbandingan 1:1 pada bak penampung sementara. Pada saat pengadukan sampah di buang dari bak penampungan. Pengadukan dilakukan hingga terbentuk lumpur dari kotoran sapi.

2. Lumpur dari bak penampungan sementara kemudian di alirkan ke digester. Pada pengisian pertama digester harus di isi sampai penuh.

3. Melakukan penambahan starter (banyak dijual dipasaran) sebanyak 1 liter dan isi rumen segar dari rumah potong hewan (RPH) sebanyak 5 karung untuk kapasitas digester 3,5 - 5,0 m2. Setelah digester penuh, kran gas ditutup supaya terjadi proses fermentasi.

4. Gas metan sudah mulai di hasilkan pada hari 10 sedangkan pada hari ke -1 sampai ke - 8 gas yang terbentuk adalah $\mathrm{CO}$. Pada komposisi $\mathrm{CH} 4$ 54\% dan $\mathrm{CO} 2$ 27\% maka biogas akan menyala.

5. Pada hari ke -14 gas yang terbentuk dapat digunakan untuk menyalakan api pada kompor gas atau kebutuhan lainnya. Mulai hari ke-14 ini kita sudah bisa menghasilkan energi biogas yang selalu terbarukan. Biogas ini tidak berbau seperti bau kotoran sapi.

6. Digester terus diisi lumpur kotoran sapi secara kontinu sehingga dihasilkan biogas yang optimal.

7. Kompos yang keluar dari digester di tampung di bak penampungan kompos. Kompos cair di kemas ke dalam deregent sedangkan jika ingin di kemas dalam karung maka kompos harus di keringkan.

Untuk mengetahui keberhasilan dari kegiatan ini, dilakukan dengan melihat keterlibatan dan antusiasme peserta. Keterlibatan peserta dapat dilihat dari absensi peserta kegiatan, sedangkan antusiasme peserta dilihat dari motivasi peserta selama kegiatan berlangsung. Setelah kegiatan pelatihan atau workshop, dilanjutkan dengan monitoring dan evaluasi oleh Tim pelaksana PPM, dengan tujuan untuk melihat dan mendampingi KTT dalam pembuatan pupuk kompos, proses pengemasan pupuk kompos dan strategi pemasaran produk pupuk kompos (pemasaran secara langsung maupun pemasaran secara online).

\section{Tahapan Pembuatan Pupuk Kompos dari Kotoran Sapi}

Masyarakat petani peternak di desa Batu Kuta Lombok Barat kesulitan untuk membeli pupuk kimia, apalagi dimasa pandemic yang terasa kesulitan ekonomi, disamping itu pupuk kimia sangat langka dan harganya pun tinggi, sehingga diperlukan ambil teknologi sebagai solusi dari permasalahan ini. Dengan adanya program PPM ini, ambil alih teknologi tersebut dapat dilaksanakan, melalui teknologi pembuatan pupuk organik. Diharapkan masyarakat nantinya dapat menggunakan pupuk tersebut sehingga tidak perlu membeli pupuk kimia. Jumlah kotoran ternak yang digunakan dalam pembuatan pupuk organik dapat digunakan dalam memprediksi jumlah pupuk yang dihasilkan. Adapun kandungan Bahan Kering (BK) dari kotoran sapi adalah $12 \%$, sedang proses fermentasi biogas dalam degester harus mengandung Bahan Kering (BK) 7 - $9 \%$ dan harus homogen apabila mengharapkan proses tersebut berlangsung dengan baik (CARE, 2009).

Nilai rata-rata bahan kering dari beberapa kotoran hewan berkisar antara $8-25$ $\%$. Total kotoran dan air untuk 1 ekor sapi adalah $53,19 \mathrm{~kg}$, terdiri dari $3,48 \mathrm{~kg}$ bahan kering dan sisanya $49.71 \mathrm{~kg}$ dalam bentuk cair. Hal ini berarti pupuk organik yang diproduksi setiap ekor sapi $3,48 \mathrm{~kg}$ berupa pupuk padat dan $49,71 \mathrm{~kg}$ dalam bentuk pupuk cair (Ir. Suhut Simamora, 2004).

Pupuk organik dapat meningkatkan kesuburan tanah dengan memperbaiki kerusakan fisik tanah akibat pemakaian pupuk anorganik (kimia) pada tanah secara berlebihan yang berakibat rusaknya struktur tanah dalam jangka waktu lama.

Pengolahan kotoran sapi yang mempunyai kandungan $\mathrm{N}, \mathrm{P}$ dan $\mathrm{K}$ yang tinggi sebagai pupuk kompos dapat mensuplai unsur hara yang dibutuhkan tanah dan memperbaiki struktur tanah menjadi lebih baik. Kotoran sapi sebagai bahan baku dalam instalsi biogas, merupakan bahan organik yang mempunyai kandungan Nitrogen $(\mathrm{N})$ tinggi disamping unsur $\mathrm{C}, \mathrm{H}$ dan $\mathrm{O}$. Selama proses pembuatan biogas unsur-unsur tersebut akan membentuk $\mathrm{CH} 4$ dan $\mathrm{CO} 2$, sedangkan kandungan $\mathrm{N}$ yang ada masih tetap bertahan dalam sisa bahan setelah diproses, yang akhirnya akan menjadi sumber $\mathrm{N}$ bagi pupuk organik.

Pupuk organik selain dapat diperoleh dari limbah atau sisa buangan pada saat pembuatan biogas, juga dapat dibuat langsung dari kotoran ternak. Pembuatan kompos langsung dari kotoran ternak, diawali dengan pengumpulan kotoran sapi dengan cara pemanenan dari kandang sistem kelompok, dilanjutkan dengan proses pengolahan menjadi kompos curah, blok, granula dan bokhasi (PRIHANDINI \& PURWANTO, 2007) 


\section{HASIL DAN PEMBAHASAN}

Mengacu pada rancangan evaluasi kegiatan, tahapan kegiatan PPM, diuraikan sebagai berikut:

1. Sosialisasi/Penyuluhan Pelatihan/Workshop

dan

Kegiatan pelatihan atau workshop tentang "Pengolahan Limbah Kotoran Sapi menjadi Energi Gas Non Fosil dan Pupuk Organik", meliputi: Penyampaian Materi tentang instalasi energi gas non fosil/biogas dan pembuatan kompos dari kotoran sapi yang akan dilanjutkan dengan pembuatan instalasi biogas dan pembuatan pupuk kompos.

Berdasarkan hasil pantauan kegiatan dari Tim PPM selama kegiatan sosialisasi dan pelatihan berlangsung, setelah diberikan sosialisasi oleh Tim PPM tentang pentingnya serta manfaat dari program ini bagi KTT Wiresinge, seluruh peserta kegiatan terlihat antusias dalam menyimak dan berpartisipasi pada instalasi biogas dan dalam mempraktekkan pembuatan pupuk kompos. Berdasarkan hasil diskusi dan wawancara dengan peserta kegiatan PPM, maka dapat disimpulkan terjadinya peningkatan pengetahuan petani peternak tentang pemanfaatan limbah peternakan sapi sebagai penghasil biogas dan pupuk organik.

Adapun bentuk partisipasi petani peternak dari KTT Wiresinge dalam pelaksanaan program PPM, diantaranya;

1. Menyediakan sarana dan prasarana dalam pelaksanaan program PPM, seperti lokasi dan peralatan penunjang pelatihan/workshop

2. Menyediakan materi pelatihan/workshop: kandang, ternak, pakan, kotoran ternak, dan air.

3. Berperan aktif dalam pelatihan/workhop:Instalasi energi gas non fosil/biogas dan workshop tentang pembuatan kompos dari kotoran sapi.

\section{Instalasi Biogas dan Residu Biogas serta Pemeliharaannya}

Pembuatan Instalasi Biogas dimulai pada 19 April 2021. Kegiatan instalasi biogas ini dimulai dengan pembuatan digester. Digester ini disesuaikan dengan skala kepemilikan ternak sapi yang dimiliki oleh petani peternak yaitu 1-3 ekor (Kusumawati, 2012), disamping itu disesuaikan pula dengan luas halaman, serta lokasi digester harus dekat dengan kandang dan dapat menjangkau sumber air seperti sumur, PDAM dan sumber air lainnya.
Instalasi biogas dapat dikerjakan dengan baik selama 14 hari. Biogas akan diproduksi setelah proses fermentasi bahan organik pada digester selama 15- 40 hari (Ninik Indawati, 2020). Dalam kegiatan PPM ini, biogas dihasilkan setelah proses fermentasi pada digester selama 17 hari. Biogas yang diproduksi disalurkan ke kompor, digunakan sebagai sumber energi alternatif pengganti elpiji atau minyak tanah.

Untuk menghasilkan biogas, maka digester harus mendapatkan suplai material input berupa limbah atau kotoran sapi. Imbangan antara senyawa karbon dan nitrogen mempengaruhi keberhasilan produksi biogas. Imbangan C:N yang cukup untuk produksi biogas adalah 20:30 (Lingkungan, 2008).

Residu biogas akan dapat digunakan setelah dipisahkan dari ruang residu yang terdapat pada instalasi biogas. Residu biogas tersebut dipindahkan ke instalasi khusus residu biogas kemudian dihamparkan di lantai datar untuk dikeringkan di bawah sinar matahari selama kurang lebih 14 hari (Ninik Indawati, 2020). Berdasarkan hasil tinjauan fisik di lapang, residu limbah biogas setelah dianginanginkan selama tujuh (7) hari layak dijadikan sebagai pupuk organik siap jual karena sesuai dengan kondisi fisik yang diharapkan.

Adapun indikator capaian yang diharapkan pada kegiatan PPM ini yaitu pemahaman masyarakat atau petani peternak di desa Batu Kuta tentang proses pembuatan instalasi biogas dan residu biogas dengan cara pengamatan secara langsung di lokasi yang dijadikan percontohan. Dalam kegiatan ini, ada 2 (dua) lokasi atau titik atau Kepala Keluarga (KK) yang dijadikan percontohan pemasangan atau instalasi biogas. Adapun alasan instalasi biogas hanya dapat dilakukan pada 2 (dua) titik atau lokasi, hal ini disebabkan oleh keterbatasan dana dalam pelaksanaan program ini, disamping terbatasnya jumlah petani peternak yang memiliki halaman memadai untuk instalasi biogas atau pembuatan digester.

Berdasarkan hasil pantauan di lapangan, bahwa seluruh peserta ikut berpartisipasi dalam kegiatan instalasi biogas dan pembuatan pupuk kandang, walaupun instalasi biogas hanya dapat dipasang pada 2 (dua) titik atau dua rumah tangga, tetapi hal ini tidak menurunkan semangat atau motivasi petani peternak dari KTT Wiresinge dalam mendukung pelaksanaan program PPM ini, walaupun 
sebelumnya Tim PPM mendapatkan kesulitan dalam menentukan 2 (dua) titik lokasi pembangunan digester karena masing-masing peserta dari KTT Wiresinge memiliki kesempatan yang sama untuk dipilih sebagai lokasi pembuatan digester, sementara dana kegiatan PPM terbatas, namun setelah Tim PPM memberikan penjelasan tentang keterbatasan dana dalam pelaksanaan PPM, dan ada beberapa kriteria dalam menentukan titik atau lokasi pembuatan digester seperti disebutkan diatas, maka kendala tersebut dapat diatasi.

\section{Pembuatan Pupuk Kompos}

Pembuatan pupuk kompos dilaksanakan pada 17 Juni 2021. Pembuatan pupuk organik ini menggunakan kotoran sapi yang dicampur dengan stardec atau EM4 sebagai dekomposernya, abu, Sekam atau "gergajen" (limbah gergajian kayu), dan kapur bubuk (PRIHANDINI \& PURWANTO, 2007). Peserta dari KTT Wiresinge sangat antusias mengikuti proses pembuatan pupuk organik tersebut.

4. Evaluasi Ekonomi dan Analisa Keuangan Berdasarkan analisis keuangan (Kumparan, 2021), evaluasi pengeluaran terhadap penggunaan biogas, dapat diasumsikan sebagai berikut: 1 (satu) $\mathrm{m} 3$ biogas memiliki kesetaraan dengan elpiji $0,46 \mathrm{~kg}$, minyak tanah 0,62 liter, bensin 0,80 liter, dan kayu bakar $3,5 \mathrm{~kg}$. Dalam keadaan normal 2 (dua) ekor sapi menghasilkan 4,14 $\mathrm{m} 3$ biogas/hari yang setara dengan $1,90 \mathrm{~kg}$ elpiji atau 2,56 liter minyak tanah. Adapun rata-rata pemakaian minyak tanah per kepala keluarga di desa Batu Kuta adalah 1.5 liter/hari. Harga minyak tanah di desa Batu Kuta adalah Rp 14.000,00/liter (Hasil wawancara dengan masyarakat di desa Batu Kuta Lombok Barat). Berdasarkan asumsi ter

sebut maka petani peternak tidak perlu mengeluarkan biaya untuk membeli bahan bakar konvensional atau dapat dikatakan melakukan penghematan sebesar Rp 21.000,00/hari atau Rp.630.000,00/bulan.

Disamping keuntungan secara material yang dapat diperoleh dari penggunaan biogas karena dapat menghemat penggunaan energi bahan bakar, keuntungan lain dapat diperoleh dari produk pupuk organik. Pupuk organik yang merupakan produk sampingan dari prosesing biogas dapat dipasarkan dengan harga Rp 6000,00/kg. Diasumsikan, jika dalam satu bulan diproduksi $50 \mathrm{~kg}$ pupuk organik, maka akan diperoleh pendapatan dari hasil penjualan pupuk organik tersebut sebesar Rp 300.000,00/bulan

\section{Evaluasi Keadaan Sebelum dan Sesudah Program PPM}

Berdasarkan tinjauan lapangan, ada beberapa perubahan keadaan yang terjadi di desa Batu Kuta Lombok Barat, khususnya pada petani peternak KTT Wiresinge seperti tertera pada Tabel 1, dibawah ini.

Tabel 1. Perubahan setelah pelaksanaan program Pengabdian Pada Masyarakat (PPM)

\begin{tabular}{|c|c|c|c|}
\hline No. & Nama Kegiatan & Sebelum PPM & Sesudah PPM \\
\hline \multirow[t]{2}{*}{1.} & $\begin{array}{l}\text { Pemanfaatan kotoran sapi } \\
\text { menjadi energi gas non } \\
\text { fosil (biogas) }\end{array}$ & $\begin{array}{ll} & \text { Belum ada instalasi } \\
\text { biogas } \\
\text { - } \quad \begin{array}{l}\text { Tumpukkan kotoran sapi } \\
\text { dibelakang kendang }\end{array}\end{array}$ & $\begin{array}{ll}\text { - } & \text { Ada instalasi biogas } \\
\text { - } & \text { Pengolahan menjadi } \\
\text { biogas dan pupuk } \\
\text { kompos }\end{array}$ \\
\hline & & $\begin{array}{l}\text { - Pengeluaran minyak } \\
\text { tanah } \\
\text { Rp.630.000,00/bulan }\end{array}$ & $\begin{array}{l}\text { - Pengeluaran minyak } \\
\text { tanah Rp 0,-/bulan }\end{array}$ \\
\hline 2. & $\begin{array}{l}\text { Pembuatan kompos dari } \\
\text { kotoran sapi }\end{array}$ & $\begin{array}{ll}\text { - } & \text { Tersendat, } 1000 \mathrm{~kg} / \mathrm{thn} \\
\text { - } & \text { Hasil penjualan } \\
& \text { rendah/tersendat }\end{array}$ & $\begin{array}{ll}\text { - } & \text { Kapasitas produk } \\
& 10.000 \mathrm{~kg} / \mathrm{tahun} \\
\text { - } & \text { Hasil penjualan } \\
& \text { meningkat karena } \\
\text { produksi meningkat }\end{array}$ \\
\hline
\end{tabular}

Sedangkan perubahan keadaan yang terjadi setelah pemanfaatan energi non fosil/biogas, seperti yang ditunjukkan pada Gambar 1 . 


\section{Sebelum Penerapan Teknologi}

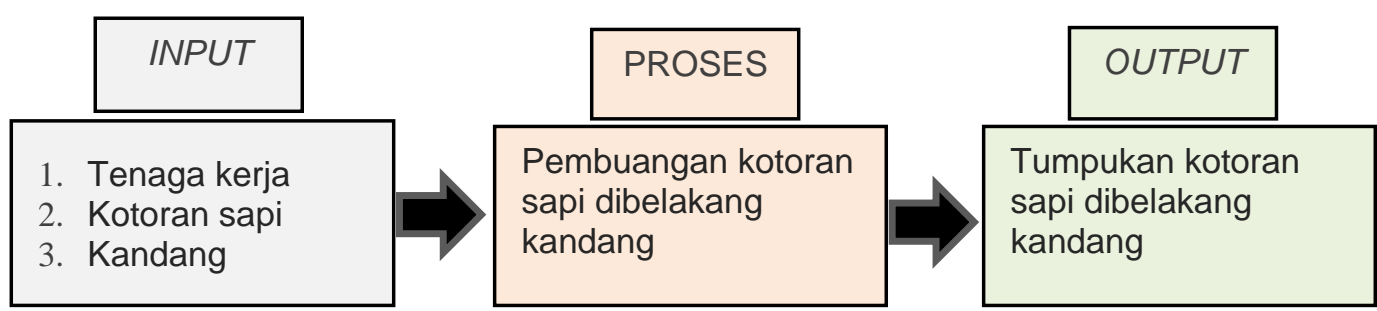

\section{Sesudah Penerapan Teknologi}

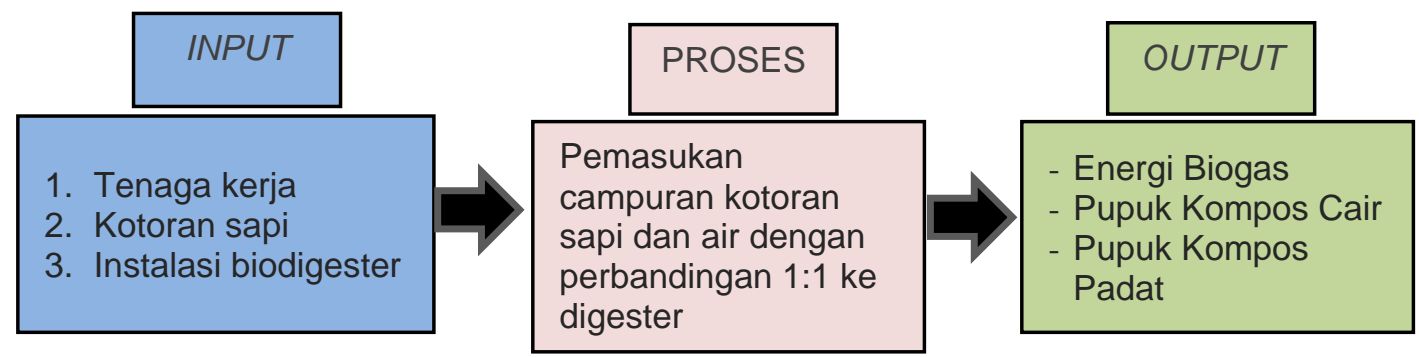

Gambar 1. Gambaran perubahan keadan setelah pelaksanaan program PPM

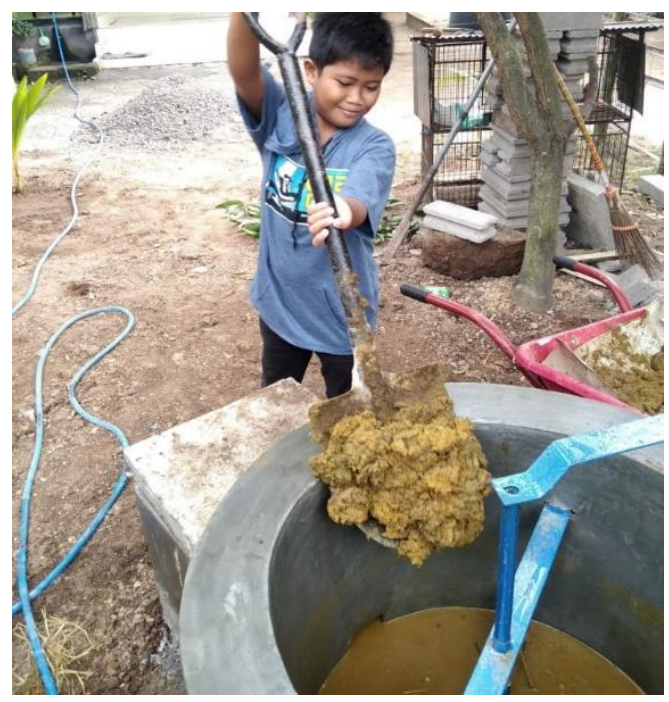

Gambar 2. Pemasukan kotoran sapi ke dalam digester biogas

Berdasarkan Tabel 1 dan Gambar 1 di atas, dapat disimpulkan bahwa terjadinya peningkatan keadaan ekonomi atau pendapatan petani peternak KTT Wiresinge di desa Batu Kuta Lombok Barat setelah pelaksanaan program PPM ini. Terjadinya perubahan keadaan yang signifikan yaitu terjadi penghematan pengeluaran sebesar Rp.630.000,00/bulan dari penggunaan biogas dan terjadi peningkatan pendapatan sebesar $\mathrm{Rp} 300.000,00 /$ bulan dari hasil penjualan produk pupuk kompos.

\section{SIMPULAN DAN SARAN Simpulan}

Program PPM ini berjalan secara baik dan lancar, serta mampu meningkatkan motivasi masyarakat di desa Batu Kuta Lombok Barat, khususnya masyarakat yang bergabung dalam kelompok tani ternak (KTT) Wiresinge baik dalam pelaksanaan program, dalam mempraktekkan instalasi biogas maupun dalam pembuatan pupuk kompos. Program ini sangat dirasakan manfaatnya oleh masyarakat di desa Batu Kuta Lombok Barat karena dapat menghemat penggunaan bahan bakar, disamping itu dapat meningkatkan pendapatan masyarakat melalui usaha produk pupuk kompos, yang tentunya secara tidak langsung akan meningkatkan kesejahteraan masyarakat.

\section{Saran}

Program ini perlu diterapkan pada daerah/desa lain dengan kondisi pertanian peternakan yang memadai dan perlu pendampingan dalam hal pengelolaan keuangan.

\section{UCAPAN TERIMA KASIH}

Ucapan terima kasih kami sampaikan kepada Kementerian Pendidikan, Kebudayaan, Riset dan Teknologi, Badan Penelitian dan Pengembangan dan Perbukuan yang telah mendanai sepenuhnya kegiatan Pengabdian Kepada Masyarakat ini melalui Program Kemitraan Masyarakat sesuai $\mathrm{SP} 2 \mathrm{H}$ No. 091/SP2H/PPM/DRPM/2021, semua instansi maupun perseorangan yang telah memberikan 
dukungan moril dan materiil selama pelaksanaan kegiatan.

\section{DAFTAR RUJUKAN}

CARE, K. (2009). Cara Mudah Membuat Digester Biogas. Retrieved from https://www.academia.edu/24720628/ Cara Mudah Membuat Digester Bio gas. Retrieved 12 Juli 2021 https://www.academia.edu/24720628/ Cara Mudah Membuat Digester Bio gas

Ir. Suhut Simamora, M. I. S., Msi. (2004). Meningkatkan Kualitas Kompos. Retrieved from https://agromedia.net/katalog/meningk atkan-kualitas-kompos/. Retrieved 12 Juli 2021, from Agromedia Pustaka, Jakarta.

https://agromedia.net/katalog/meningk atkan-kualitas-kompos/

Kumparan [B. Bisnis]. (2021). 12/3/2021. Retrieved from

https://kumparan.com/berita-

bisnis/macam-macam-rumus-rasiokeuangan-dan-cara-menghitungnya1vLEI9izciZ/full

Kusumawati, W. d. D. (2012). Laporan program penerapan Iptek pemanfaatan limbah peternakan sapi potong sebagai penghasil Biogas dengan Biodigester Drum plastik dan pupuk organik. . Retrieved

from https://core.ac.uk/download/pdf/23131 6242.pdf

Lingkungan, A. [M. E. Ir. M. Syarif TJan]. (2008). Selasa, 16 Desember 2008. Retrieved 12 Juli 2021 from https://analislingkungan.blogspot.com/ 2008/12/cara-mudah-membuatdigester-biogas.html

Ninik Indawati, E. D. K., Waluyo Edi Susanto (2020). PEMANFAATAN LIMBAH KOTORAN TERNAK SAPI MENJADI BIOGAS DAN PUPUK ORGANIK Retrieved from https://core.ac.uk/download/pdf/23131 6242.pdf

PRIHANDINI, P. W., \& PURWANTO, T. (2007). PETUNJUK TEKNIS PEMBUATAN KOMPOS BERBAHAN KOTORAN SAPI Loka Penelitian Sapi Potong. Jln. Pahlawan Grati No. 2 Grati Pasuruan 67184: PPUSAT PENELITIAN DAN PENGEMBANGAN PETERNAKAN BADAN PENELITIAN DAN PENGEMBANGAN PERTANIAN DEPARTEMEN PERTANIAN 2007

Statistik, B. P. (2020). KECAMATAN NARMADA DALAM ANGKA Narmada
Subdistrict in Figures. Narmada, Lombok Barat, Nusa Tenggara Barat: CBPS Kabupaten Lombok Barat/Statistic of Lombok Barat Regency Retrieved from https://lombokbaratkab.bps.go.id

Wikipedia. (2020). Kota Mataram. Retrieved from

https://id.wikipedia.org/wiki/Kota Mata ram. Retrieved 14 Juni 2021, pukul 14.26.

https://id.wikipedia.org/wiki/Kota Mata $\underline{\text { ram }}$ 